\title{
Thinlip grey mullet Liza ramada (Mugilidae) caught in a small Norwegian stream
}

\author{
Bror Jonsson and Nina Jonsson
}

\begin{abstract}
Jonsson B and Jonsson N. 2008. Thinlip grey mullet Liza ramada (Mugilidae) caught in a small Norwegian stream. Fauna norvegica 26/27: 31-33.

Two individuals of thinlip grey mullet Liza ramada were collected in a southern Norwegian brook $\left(58^{\circ} 22^{\prime} \mathrm{N}, 8^{\circ} 37^{\prime} \mathrm{E}\right)$ on 12th September 2007. The fish were 8.7 and $9.0 \mathrm{~cm}$ in total length, 6 and 7 $\mathrm{g}$ in total mass, and most probably in their first year of life. The nearest known spawning area of the species is south of the English Channel, meaning that they had probably moved at least $900 \mathrm{~km}$ across the North Sea during their first growth season. To our knowledge, this is the first published observation of the catadromous thinlip grey mullet from a Scandinavian freshwater course.
\end{abstract}

Keywords: Liza ramada, catadromous, freshwater, young-of the year, Norway

Bror Jonsson, Norwegian Institute for Nature Research, Gaustadalléen 21, NO-0349 Oslo, Norway Nina Jonsson, Norwegian Institute for Nature Research, Gaustadalléen 21, NO-0349 Oslo, Norway

Corresponding author: Bror Jonsson, phone: +47-73801764, fax: +47-22600424

E-mail: bror.jonsson@nina.no

The thinlip grey mullet Liza ramada Risso, 1826 (Mugilidae) is a migratory species classified as rare in the North Sea where it is sometimes caught along the Atlantic coast (Whitehead et al. 1986, Pethon 2005). Here we report thinlip grey mullet from a small brook in southern Norway.

During an electrofishing survey in coastal streams along the Skagerrak coast, two thinlip grey mullets (Liza ramada) were collected on 12th September 2007 at $15.30 \mathrm{hrs}$ in the Sævelibekken ( $\left.58^{\circ} 22^{\prime} \mathrm{N}, 8^{\circ} 37^{\prime} \mathrm{E}\right)$, a small brook near Grimstad town, southern Norway. The fish were anaesthetized with clove oil. They were 8.7 and $9.0 \mathrm{~cm}$ in total length with total wet masses of 6 and $7 \mathrm{~g}$, respectively. Judged from their sizes, the fish were in their first year of life. They were photographed and after recovering from the anaesthetization, carefully returned to the brook and placed at the same location where they were caught.

The two individuals co-occurred in shallow water $(\mathrm{ca} .10 \mathrm{~cm})$ over gravel substratum ca. $100 \mathrm{~m}$ above the stream outlet. Water temperature at the time of sampling was $12{ }^{\circ} \mathrm{C}$. The
Sævelibekken is a small brook with estimated mean annual water flow at $0.05 \mathrm{~m}^{3} \mathrm{~s}^{-1}$ (Jonsson et al. 2001). The brook water is fresh with specific conductivity of 11.5. Concentration of total phosphorus was $16.6 \mu \mathrm{g} / \mathrm{l}$, total calcium was $5.22 \mathrm{mg} / \mathrm{l}$, total organic carbon was $8.8 \mathrm{mg} / 1, \mathrm{pH} 6.94$, and the turbidity was 3.7 Formazin Turbidity Units (FTU). Sævelibekken also supports anadromous brown trout Salmo trutta Linnaeus, 1758 and threespine stickleback Gasterosteus aculeatus (Linnaeus, 1758), and catadromous European eel Anguilla anguilla (Linnaeus, 1758), flounder Platichthys flesus (Linnaeus, 1758) and gobiids Pomatoschistus sp.

The grey mullets are easily recognized by the two widely separated small dorsal fins, the anterior dorsal fin has 4 slender spines, the posterior dorsal fin is soft-rayed. The lateral line is absent. The thinlip grey mullet has silvery grey sides, a white belly and a dark grey back. It has a dark spot at the upper end of the base of the pectoral fins, and the upper lip, which has no papillae, is on its thickest narrower than the pupil of the eye (Figure 1), distinguishing it from thicklip grey mullet Chelon labrosus (Risso, 1826). Furthermore, it has no yellow spot on 
the gill cover like the golden grey mullet (Liza aurata Risso, 1810) (Whitehead et al. 1986, Kottelat and Freyhof 2007).

Thinlip grey mullet is distributed in the east Atlantic from Morocco to south Norway including the Mediterranean and Black Seas $\left(20-60^{\circ} \mathrm{N}, 18^{\circ} \mathrm{E}-42^{\circ} \mathrm{W}\right)$ (www.fishbase.org/) and Baltic Sea (www.eurocoml.org/), and spawns in sea water near the coast northwards to south England (Pethon 2005). The spawning season is between September and February, and they spawn in pelagic waters (Koutrakis et al. 1994).

Thinlip grey mullet has pelagic eggs and larvae. In southern Europe, the young-of-the-year seek to the coast for feeding from February-March onwards (Bartulovic et al. 2007). They live usually inshore, entering lagoons and estuaries and are found in shallow brackish waters. Furthermore, this species is euryhaline and can exploit fresh water habitats for months as the cost of ionic regulation in fresh water is small, and they tolerate abrupt changes in water salinity (Thomson 1990, Cardona 2006). Thinlip grey mullet is classified as catadromous as it enters rivers and lakes for feeding at temperatures between 8 and $24{ }^{\circ} \mathrm{C}$ (Bartulovic et al. 2007). The young are fast growing and reach 10-12 cm in length during the first year (Almeida et al. 1995). If the observed individuals were spawned south of the English Channel, they must have moved about $900 \mathrm{~km}$ to reach south Norway during their first growth season.

Our observation shows that young-of-the-year thinlip grey mullets enter fresh water. Oliveira and Ferreira (1997) found only fish 2 years and older when they studied the species in an Iberian river. They suggested that small fish may be less resistant to fresh water than adults. However, we have found no further support for their contention. The ecology of young thinlip grey mullet is not well known, but according to Salgado et al. (2004) the juveniles may often feed in intertidal creeks and small brooks in river deltas. The small Sævelibekken brook may be a similar habitat as that described by Salgado et al. (2004). It empties into a shallow bay with brackish water also exploited by young brown trout Salmo trutta longer than ca. 6 $\mathrm{cm}$ (Jonsson et al. 2001).

The occurrence of thinlip grey mullet in northern Europe is not well known. Whitehead et al. (1986) presented a geographic distribution of the species in the sea northwards to southernmost Norway, and Pethon (2005) reported Trøndelag $\left(\sim 63^{\circ} \mathrm{N}\right)$ as the northern species limit. We have found no mentioning about any North European observation of thinlip grey mullets from fresh water. Obviously, there is a need of a biodiversity-oriented monitoring that covers coastal water courses integrating both marine and freshwater habitats, at a wide range and at regular intervals. Such a research program would also generate important implications related to climate-change.

\section{ACKNOWLEDGEMENTS}

The water chemistry was analyzed by Analysesenteret, Trondheim. This research was economically supported by NINAs strategical institute programme "EcoDrivers".

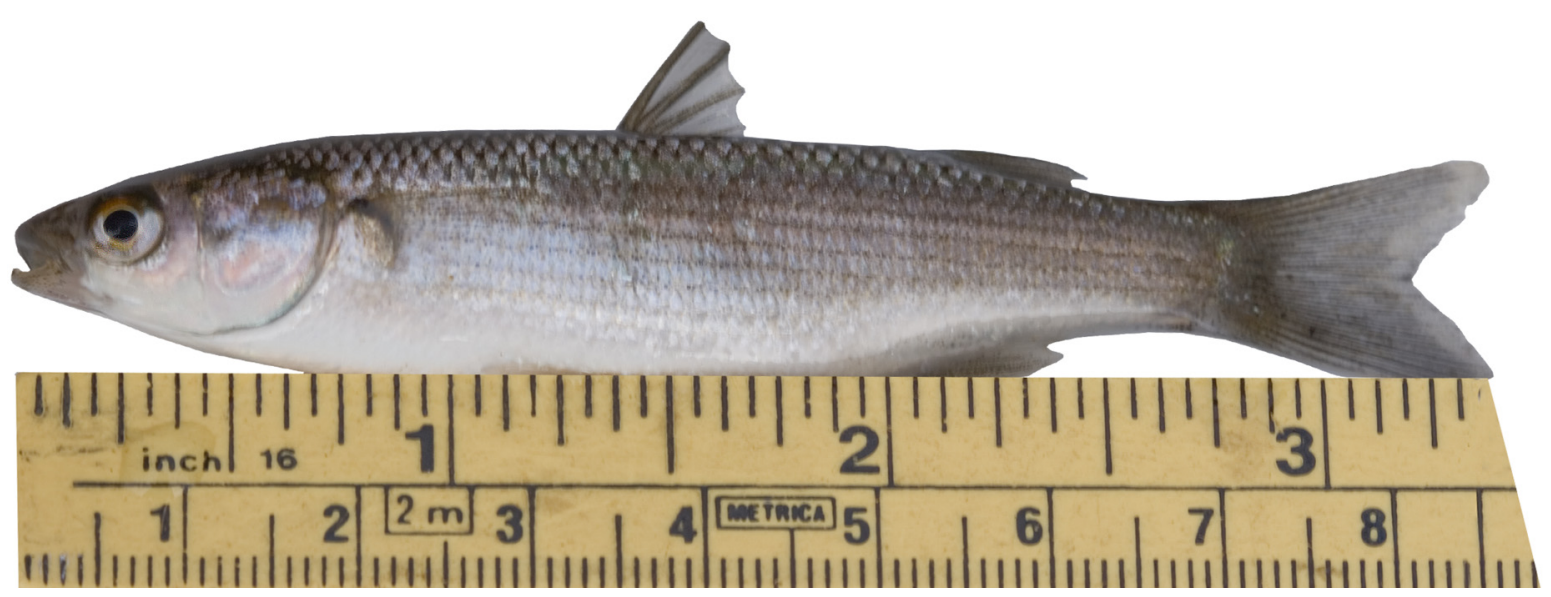

Figure I. Thinlip grey mullet Liza ramada caught in the small brook Sævelibekken, southern Norway. 


\section{REFERENCES}

Almeida, P.R., Moreira, F.M., Domingos, I.M. Costa, J.L., Assis, C.A. and Costa, M.J. 1995. Age and growth of Liza ramada (Risso, 1826) in the River Tagus, Portugal. Scientia Marina 59: 143-147.

Bartulovic, V., Glamuzina, B., Lucic, D., Conides, A., Jasprica, N. and Dulcic, J. 2007. Recruitment and food composition of juvenile thin-lipped grey mullet, Liza ramada (Risso, 1926), in the Neveta River Estuary (Eastern Adriatic, Croatia). Acta Adriatica 48: 25-37.

Cardona, L. 2006. Habitat selection by grey mullets (Osteichthyes: Mugilidae) in Mediterranean estuaries: the role of salinity. Scientia Marina 70: 443-455.

Jonsson, B., Jonsson, N., Brodtkorb, E. \& Ingebrigtsen, P.-J. 2001. Life history traits of brown trout vary with the size of small streams. Functional Ecology 15: 310-317.

Kottelat, M. \& Freyhof, J. 2007. Handbook of European freshwater fishes. IUCN, Delemont, Switzerland.

Koutrakis, E.T., Sinis, A.I., \& Economides, P.S. 1994. Seasonal occurrence, abundance and size distribution of grey mullet fry (Pisces, Mugilidae) in the Porto-Lagos lagoon and Lake Vistonis (Aegean Sea, Greece). Israeli Journal of Aquaculture Bamidgeh 46: 182-196.

Oliveira, J.M. \& Ferreira, M.T. 1997. Abundance, size composition and growth of a thinlipped grey mullet, Liza ramada (Pisces: Mugilidae) population in an Iberian river. Folia Zoologica 46: 375-384.

Pethon, P. 2005. Aschehougs store fiskebok. 5th edition. - H. Aschehoug \& Co, Oslo. (In Norwegian). $468 \mathrm{p}$.

Selgado, J., Costa, M.J., Cabral, H., \& Deegan, L. 2004. Comparison of the fish assemblages in tidal salt marsh creeks and in adjoining mudflat areas in the Tejo estuary (Portugal). Cahiers de Biologie Marine 45: 213-224.

Thomson, J.M. 1990. Mugelidae.- Pp. 857-858 in J.C. Quero, J.C. Hureau, C.A. Post and L. Saldanha (eds.). Check-list of the fishes of the eastern tropical Atlantic, vol. II. - UNESCO, Paris, France.

Whitehead, P.J.P., Bauchot, M.-L., Hureau, J.-C., Nielsen, J., and Tortonese, E. 1986. Fishes, of the North-eastern Atlantic and the Mediterranean, vol. III. - UNESCO, Paris, France. 